\title{
Vitamin B12 Blood Level is Correlated with Drug-Induced Extrapyramidal Symptoms in Schizophrenic Patients
}

\author{
EMILIA BURADA ${ }^{1 \#, ~ I L E A N A ~ M A R I N E S C U #, ~ O T I L I A ~ C O N S T A N T I N A ~ R O G O V E A N U 3 \#, ~ A M E L I A-M I H A E L A ~ D O B R E S C U 4, ~}$ \\ CITO TAISESCU ${ }^{1}$, FLORIN BURADA*, VERONICA SFREDEL ${ }^{1}$, TUDOR ADRIAN BALSEANU ${ }^{1}$ \\ University of Medicine and Pharmacy of Craiova, Faculty of Medicine, Department of Physiology, 2-4 Petru Rares Str, 200349, \\ Craiova, Romania \\ 2University of Medicine and Pharmacy of Craiova, Faculty of Medicine, Department of Psychiatry, 2-4 Petru Rares Str, 200349, \\ Craiova, Romania \\ ${ }^{3}$ University of Medicine and Pharmacy of Craiova, Faculty of Medicine, Department of Physical Medicine and Rehabilitation, \\ 2-4 Petru Rares Str, 200349, Craiova, Romania \\ ${ }^{4}$ University of Medicine and Pharmacy of Craiova, Human Genomics Laboratory, 66, 1 Mai Str, 200639, Craiova, Romania
}

\begin{abstract}
The extrapyramidal symptoms (EPS) are commonly associated with antipsychotic treatment of schizophrenic patients. Accumulated evidence has shown that pathways of homocysteine and folate metabolism are linked to neurodegeneration and schizophrenia. The purpose of our study was to evaluate the homocysteine, vitamin B12 and folate serum levels in relation to drug-induced EPS in schizophrenic patients. The blood levels of homocysteine, vitamin B12 and folic acid were measured by chemiluminescent and electrochemoluminescence immunoassay methods in 34 patients diagnosed with schizophrenia (19 patients with severe EPS and 15 controls without EPS), recruited from Clinical Hospital of Neuropsychiatry Craiova, Romania. A significant association has been observed between EPS and vitamin B12 levels, the patients with severe EPS showed a reduced vitamin B12 levels $(p=0.02)$. No correlation was observed between severe EPS and homocysteine or folate levels $(p=0.2$, respectively $p=0.37)$. Our study suggests that deficiency of vitamin B12 blood levels is correlated with severe EPS in schizophrenic patients. Further studies included more patients and functional experiments are required to clarify the role of these biomarkers in relation with antipsychotic-induced EPS in schizophrenia.
\end{abstract}

Keywords: extrapyramidal symptoms (EPS), schizophrenia, homocysteine, vitamin B12, folate

Schizophrenia is an important health problem with substantial personal, social and economic impact, affecting almost $1 \%$ of the adult population [1]. The primary treatment of schizophrenia is medication and the reduced compliance to antipsychotics remains a major issue [2], mainly due to drug-induced extrapyramidal symptoms (EPS) such as dystonia, parkinsonism, akathisia, catatonia or tardive dyskinesia [3-5]. The mechanisms of EPS development, especially produced by the firstgeneration of antipsychotics remains unclear although several hypotheses have been proposed (e.g. blocking dopamine receptors, especially D2 receptors cause parkinsonism and akathisia) $[6,7]$. Also, the antipsychotic treatment can induce metabolic adverse events and abnormalities, mainly when no pharmacogenetic testing is performed previously in psychotic patients [8].

The neurodevelopmental and neurodegenerative models are two currently accepted theories to explain the etiology and the clinical course of schizophrenia [9]. Accumulated evidence shows that elevated levels of homocysteine (Hcy) could be linked to neurodegeneration [10-12]. An increased level of Hcy was correlated with different conditions, including Alzheimer disease, vascular dementia, cognitive impairment, autism, Huntington disease and schizophrenia [13-16]. However, it is unclear if a higher level of Hcy is a risk factor or these diseases lead to hyperhomocysteinemia [16-18]. In addition, a positive correlation between the levels of homocysteine and extrapyramidal effects has been reported [19, 20]. The vitamin B12 and folic acid are necessary for homocysteine conversion and their deficiency was related to psychotic disorder and EPS [21]. The folate level was negatively correlated with score of SANS symptom rating scale and it was lower in patients with than those without the deficit syndrome $[19,22,23]$. Furthermore, the B vitamin supply determine a slowing in brain atrophy and improvement in some cognitive function [13], whereas a high level of homocysteine was associated with a degree of brain atrophy in patients with mild cognitive impairment [24].

In this respect, the purpose of our study was to evaluate the homocysteine, vitamin B12 and folate blood levels in relation to drug-induced movement disorders in schizophrenic patients treated with antipsychotics.

\section{Experimental part}

Subjects and methods

In this study we included 34 schizophrenic patients (19 patients with severe EPS and 15 controls without EPS), recruited from Clinical Hospital of Neuropsychiatry Craiova, Romania. Patient demographics and clinical information were collected. The neurologic exam of included patients has been focused on the evaluation of EPS and SimpsonAngus Extrapyramidal Side Effects Scale, Abnormal Involuntary Movement Scale and Barnes Akathisia Scale were used. Cognitive function was measured using Mini Mental State Examination (MMSE) and Positive and Negative Syndrome Scale (PANSS) scales. The study was approved by the Ethics Committee of the University of Medicine and Pharmacy of Craiova, Romania and informed consent was obtained from each participant.

\section{Serological evaluation}

Peripheral blood was obtained from each included subject. The homocysteine level was evaluated by 
chemiluminescent immunoenzyme assay (Cobas 6000 Analyzer, Roche Diagnostics) and expressed in $\mu \mathrm{mol} / \mathrm{L}$. The normal range of plasma Hcy level is $5-12 \mu \mathrm{mol} / \mathrm{L}$, the cutoff point for Hcy elevation was defined as concentrations $>12 \mu \mathrm{mol} / \mathrm{L}$ based on the test manufacturer's protocol.

Vitamin B12 and folate serum levels were determined by electrochemoluminescence immunoassay method (ECLIA) performed on an Cobas 6000 Analyzer (Roche Diagnostics). The normal range of the values in our laboratory were 2.0-9.1 ng/mL for folic acid and 197-866 $\mathrm{pg} / \mathrm{mL}$ for vitamin B12.

\section{Statistical analysis}

The Mann-Whitney test was used to assess the association between EPS and homocysteine, folate, and vitamin B12 blood levels. The results were presented as mean \pm SD and a $P$ value less than 0.05 was considered statistically significant.

\section{Results and discussions}

The homocysteine, vitamin B12 and folate blood levels were measured in 34 schizophrenic patients (19 patients with severe EPS and 15 control patients without EPS). The distribution of EPS was as follows: 13 patients with parkinsonism, 4 with dyskinesia, 1 akathisia and 1 with dystonia. The characteristics of both groups are summarized in table 1 , and no significant differences in sex and age were observed between the patients and controls $(p>0.05)$. The average age of EPS group was $38.84 \pm 4.66$ years and $53 \%$ of were women. In the control group, the average age was $40.36 \pm 4.31$ years and $51 \%$ were women.

The mean value of homocysteine level vas $9.82 \mu \mathrm{mol} / \mathrm{L}$ in severe EPS group and $7.86 \mu \mathrm{mol} / \mathrm{L}$ in controls (yable 2). An abnormal level (higher than $13.9 \mu \mathrm{mol} / \mathrm{L}$ ) was measured in 3 patients (16\%) with severe EPS, how ever a higher level of homocysteine than $10 \mu \mathrm{mol} / \mathrm{L}$ was recorded in 7 patiens with severe EPS and none of the controls. All 3 patients with increased homocysteine exhibited parkinsonism as
EPS. We failed to find a statistical correlation between EPS and homocysteine levels $(p=0.2)$.

Normal values of vitamin B12 were found in 12 patients with severe EPS and 12 controls, whereas a low level was observed in 5 patients with severe EPS ( 3 with parkinsonism, one case with dyskinesia and one case with dystonia) and 3 controls, respectively. A significant association has been observed between EPS and vitamin B12 levels $(p=0.02)$. The folate level was normal in both groups, however borderline values were found in 4 patients with EPS $(<3.8 \mathrm{ng} / \mathrm{mL})$. No correlation was observed between EPS and folate levels $(p=0.37)$.

Numerous studies investigated the incidence and severity of EPS with first- and second-generation antipsychotics and only few research have examined the relationship between EPS and Hcy, vitamin B12 and folate plasma levels in schizophrenia.

In this study, we measured the Hcy, vitamin B12 and folate levels in plasma of schizophrenic patients with severe EPS. We found a significant correlation between low levels of vitamin B12 and severe EPS in schizophrenic patients, but no for Hcy and folate.

The Hcy was proposed as biomarker for monitoring treatment and managing adherence in schizophrenia or as a predictor of the severity of side effects. The level of $\mathrm{Hcy}$ is dependent on many factors including age, lifestyle and genetic factors. A high level of Hcy was found to induce oxidative stress in neurons and expression of some neurotransmitters (e.g. dopamine, serotonin) enhancing protein aggregation and neuroinflammation [14, 16, 25].

Hyperhomocysteinemia can be linked to schizophrenia by inducing DNA breakages, apoptosis [26, 27], oxidative stress [28-30] or by alteration of gene expression consecutively of increased levels of S-adenosylhomocysteine [27, 31, 32]. High blood levels of Hcy have been reported in schizophrenia [33-35] and Parkinson disease patients treated with levodopa [36, 37]. Moreover, high serum homocysteine levels were associated with tardive movement disorders secondary to antipsychotic

\begin{tabular}{|l|c|c|}
\hline Variable & $\begin{array}{l}\text { Schizophrenic patients } \\
\text { with severe EPS }\end{array}$ & $\begin{array}{l}\text { Schizophrenic patients } \\
\text { without EPS }\end{array}$ \\
\hline $\mathrm{N}$ & 19 & 15 \\
\hline Age, mean SD (years) & $38.84 \pm 4.66$ & $40.36 \pm 4.31$ \\
\hline Male & 9 & 7 \\
\hline Female & 10 & 8 \\
\hline Parkinsonism & 13 & \\
\hline Dyskinesia & 4 & \\
\hline Akathisia & 1 & \\
\hline Dystonia & 1 & \\
\hline
\end{tabular}

Table 1

CHARACTERISTICS OF SCHIZOPHRENIC PATIENTS GROUPS

\begin{tabular}{|l|c|c|}
\hline Biological marker & $\begin{array}{c}\text { Schizophrenic patients } \\
\text { with severe EPS }\end{array}$ & $\begin{array}{c}\text { Schizophrenic patients } \\
\text { without EPS }\end{array}$ \\
\hline Homocysteine $(\mu \mathrm{mo} / \mathrm{L})$, mean \pm SD & $9.82 \pm 4.5$ & $7.86 \pm 1.42$ \\
\hline B12 vitamin $(\mathrm{pg} / \mathrm{mL})$, mean mean \pm SD & $288 \pm 123$ & $391 \pm 89$ \\
\hline Folate $(\mathrm{ng} / \mathrm{mL})$, mean \pm SD & $4.84 \pm 1.49$ & $5.32 \pm 1.24$ \\
& & \\
\hline
\end{tabular}

Table 2

THE MEDIAN VALUE OF BIOLOGICAL MARKERS 
treatment, including late-onset parkinsonism and late dyskinesia, especially in young patients with affective schizophrenia [20].

The $B$ vitamins and folate are required for homocysteine metabolism and their deficiency lead to hyperhomocysteinemia and neurodegeneration by disruption of the balance of striatal activity [38]. Previous studies showed reduced blood levels of folate and vitamin B12 in various cohorts of schizophrenic patients [33,34]. In contrast, others found no difference between patients and healthy controls $[35,39]$ or even higher values of serum cobalamin than healthy controls [40]. The patients with vitamin B12 deficiency treated with antipsychotics developed extrapyramidal side effects reversed by B12 supplementation [41]. Also, vitamin B12 deficiency caused EPS in a non-antipsychotic treated patient with reversible bilateral globus pallidus abnormalities as a possible explanation [42].

It was hypothesized that supplementation of B6, folate, and B12 may help decrease Hcy levels and improve symptoms of schizophrenia [40]. Vitamin supplementation was found to be effective in improving negative symptoms [43] and PANSS scores [44], mainly for patients with hyperhomocysteinemia and particular genotypes [45].

\section{Conclusions}

The antipsychotic treatment can induce EPS, mainly parkinsonism and dyskinesia. Our study suggests that deficiency of vitamin B12 blood levels is associated with severe EPS in schizophrenic patients. The homocysteine and folate blood levels are not correlated with EPS. Further studies included more patients and functional experiments are required to clarify the role of these biomarkers in relation with antipsychotic-induced EPS in schizophrenia.

\section{References}

1. MCGRATH, J., SAHA, S., CHANT, D., WELHAM, J., Epidemiol. Rev., 30, 2008, p. 67

2. FURNICA, C., LEON CONSTANTIN, M.M, CHISTOL, R.O., ALEXA, A.I., CONSTANTIN, S., TINICA, G., Rev. Chim. (Bucharest), 66, no. 11, 2015, p. 1864

3. CAROFF, S.N., HURFORD, I., LYBRAND, J., CAMPBELL, E.C., Neurol. Clin., 29, no. 1, 2011, p. 127

4. ROSSI, G., FREDIANI, S., ROSSI, R., ROSSI, A., BMC Psychiatry., 12, 2012, p. 122

5.CAROFF, S.N., CAMPBELL, E.C., Psychiatr. Clin. North. Am., 39, no. 3, 2016, p. 391

6.KIRSCH, P., RONSHAUSEN, S., MIER, D., GALLHOFER, B., Pharmacopsychiatry, 40, no. 5, 2007, p. 196

7.MEHTA, S.H., MORGAN, J.C., SETHI, K.D., Neurol. Clin., 33, no. 1, 2015, p. 153

8.TALPOS, C., AGEU, L., CRISAN, S., ZAMFIR, C.L., POROCH, V., ANGHEL, M., Rev. Chim. (Bucharest), 68, no. 12, 2017, p. 3022 9. KOCHUNOV, P., HONG, L.E., Schizophr. Bull., 40, no. 4, 2014, p. 721 10.BOLDYREV, A., J ournal Neurochemical, 1, no. 1, 2007, p.14 11. FILIP, I.C., BERBECE, I.S., RADUCU, L., FLORESCU, I.P., ARDELEANU, V., JECAN, C.R., Mat. Plast., 54, no. 3, 2017, p. 415 12.BONETTI, F., BROMBO, G., ZULIANI, G., Neurodegener. Dis. Manag., 6, no. 2, 2016, p. 133

13.HERRMANN, W., OBEID, R., Clin. Chem. Lab. Med., 49, no. 3, 2011, p. 435

14.DOHERTY, G., J. Neurol. Disord., 1, no. 1, 2013, p. 107

15. JECAN, C.R., NICOLAU, A., FLORESCU, I.P., ARDELEANU, V., BERBECE, I.S., Mat. Plast., 54, no. 1, 2017, p. 89

16.SHARMA, M., TIWARI, M., TIWARI, R.K., Basic Clin. Pharmacol. Toxicol., 117, no. 5, 2015, p. 287
17. BERCEANU, C., CIUREA, E.L., CIRSTOIU, M.M., BERCEANU, S., OFITERU, A.M., MEHEDINTU, C., BERBECE, I.S., CIORTEA, R., STEPAN, A.E., BALSEANU, A.T., Rev. Chim. (Bucharest), 69, no. 9, 2018, p. 2397 18. ARDELEANU, V., BERBECE, I.S., FLORESCU, I.P., JECAN, C.R., Mat. Plast., 54, no. 1, 2017, p. 39

19.GOFF, D.C., BOTTIGLIERI, T., ARNING, E., SHIH, V., FREUDENREICH, O., EVINS, A.E., HENDERSON, D.C., BAER, L., COYLE, J., Am. J. Psychiatry, 161, no. 9, 2004, p. 1705

20.LERNER, V., MIODOWNIK, C., KAPTSAN, A., VISHNE, T., SELA, B.A., LEVINE, J., J. Clin. Psychiatry, 66, no. 12, 2005, p. 1558

21.DOGAN, M., OZDEMIR, O., SAL, E.A., DOGAN, S.Z., OZDEMIR, P., CESUR, Y., CAKSEN, H., J. Trop. Pediatr., 55, no. 3, 2009, p. 205

22. ARBUNE, M. LUCA, M.C., MATEI, N.M., EARAR, K., ARBUNE, A., VOINESCU, D., Rev.chim.(Bucharest), 67, no.2, 2016, p. 321

23. BERCEANU, C., PAITICI, S., BERCEANU, S., BRATILA, E., OFITERU, A.M., MEHEDINTU, C., BERBECE, I.S., NAVOLAN, D., OBLEAGA, C.V., BALSEANU, A.T., Rev. Chim. (Bucharest), 69, no. 8, 2018, p. 2246 24.RAJ AGOPALAN, P., HUA, X., TOGA, A.W., JACK, C.R., JR., WEINER, M.W.,THOMPSON, P.M., Neuroreport., 22, no. 8, 2011, p. 391

25.HO, P.I., ORTIZ, D., ROGERS, E., SHEA, T.B., J. Neurosci. Res.,70, no. 5,2002, p. 694

26.MATTSON, M.P., SHEA, T.B., Trends Neurosci., 26, no. 3, 2003, p. 137

27.CATTS, V.S., CATTS, S.V., Schizophr. Res., 41, no. 3, 2000, p. 405 28.HUANG, R.F., HUANG, S.M., LIN, B.S., WEI, J.S., LIU, T.Z., Life Sci., 68, no. 25, 2001, p. 2799

29. BERBECE, I.S., CONDRATOVICI-PLESEA, A., PAVEL, L., GRIGORE, C., Rev. Chim. (Bucharest), 68, no. 5, 2017, p. 1075

30. VOINESCU, D.C., CIOBOTARU, O.A., SIN, A., BARNA, O., COMAN, M., CIOBOTARU, O.C., Biotechnol Biotechnol Equip, 29:6, 1135-1141 31.J AMES, S.) ., MELNYK, S., POGRIBNA, M., POGRIBNY, I.P., CAUDILL, M.A., J Nutr, 132, no. 8, 2002, p. 23615

32. CIUBARA, A.B., TUDOR, R.C., NECHITA, L., TITA, O., CIUBARA, A., TURLIUC, S., RAFTU, G., Rev. Chim. (Bucharest), 69, no. 5, 2018, p. 1250

33.KALE, A., NAPHADE, N., SAPKALE, S., KAMARAJU, M., PILLAl, A., J OSHI, S., MAHADIK, S., Psychiatry Res., 175, no.1-2, 2010, p. 47

34.MISIAK, B., FRYDECKA, D., SLEZAK, R., PIOTROW SKI, P., KIEJ NA, A., Metab. Brain Dis., 29, no. 3, 2014, p. 661

35.HAIDEMENOS, A., KONTIS, D., GAZI, A., KALLAI, E., ALLIN, M., LUCIA, B., Prog Neuropsychopharmacol. Biol. Psychiatry, 31, no. 6, 2007, p. 1289

36.YASUI, K., KOWA, H., NAKASO, K., TAKESHIMA, T., NAKASHIMA, K., Neurology, 55, no. 3, 2000, p. 437

37. CIUBARA, A.B., NECHITA, A., TUDOR, R.C., MATEI, N.M., TUTUNARU, D., SIRBU, P.D., Rev. de cercetare si interventie sociala, 2018, vol 60, p. 174-179

38.HAGHDOOST-YAZDI, H., FRAIDOUNI, N., FARAJI, A., JAHANIHASHEMI, H., SAROOKHANI, M., Behav. Brain Res., 233, no. 2, 2012, p. 375

39.REIF, A., PFUHLMANN, B., LESCH, K.P., Prog. Neuropsychopharmacol. Biol. Psychiatry, 29, no. 7, 2005, p. 1162

40.SAEDISOMEOLIA, A., DJALALI, M., MOGHADAM, A.M., RAMEZANKHANI, O., NAJ MI, L., J. Res. Med. Sci., 16, 2011, p. S437 41.KUMANAN T, T.N., PIRASATH S. OALibj, 4, no. 3, p. e3400

42.SHARRIEF, A.Z., RAFFEL, J., ZEE, D.S., Arch .Neurol., 69, no. 6, 2012, p. 769

43.ROFFMAN, J.L., LAMBERTI, J.S., ACHTYES, E., MACKLIN, E.A., GALENDEZ, G.C., RAEKE, L.H., SILVERSTEIN, N.J., SMOLLER, J.W., HILL, M., GOFF, D.C., JAMA Psychiatry, 70, no. 5, 2013, p. 481

44.LEVINE, J., STAHL, Z., SELA, B.A., RUDERMAN, V., SHUMAICO, O., BABUSHKIN, I., OSHER, Y., BERSUDSKY, Y., BELMAKER, R.H., Biol. Psychiatry, 60, no. 3, 2006, p. 265

45. MITRA, S., NATARAJAN, R., ZIEDONIS, D., FAN, X., Prog. Neuropsychopharmacol. Biol. Psychiatry, 78, 2017, p. 1

Manuscript received: 3.08 .2018 